\title{
FINANCIAL SUPPORT AND DEVELOPMENT OF DIGITAL RURAL HUBS IN EUROPE
}

\author{
Mykhailo Dyba $^{1}$, Iuliia Gernego ${ }^{2}$, Oleksandr Dyba ${ }^{3}$, Alla Oliynyk ${ }^{4}$ \\ ${ }^{1}$ Dr. Sc., Professor SHEE, Kyiv national economic university named after V. Hetmana, 54/1 Peremohy Ave, \\ Kyiv, Ukraine, E-mail address: dyba m@ukr.net \\ ${ }^{2}$ Ph. D., SHEE, Kyiv national economic university named after V. Hetmana, 54/1 Peremohy Ave, Kyiv, Ukraine, \\ Phone Number+380962218313, E-mail address iuliiagern@ukr.net \\ ${ }^{3}$ Dr. Sc., Professor SHEE, Kyiv national economic university named after V. Hetmana, 54/1 Peremohy Ave, \\ Kyiv, Ukraine,E-mail address dyba m@ukr.net \\ ${ }^{4}$ PhD student SHEE, Kyiv national economic university named after V. Hetmana, 54/1 Peremohy Ave, Kyiv, Ukraine, \\ E-mail address 072 alla@ukr.net
}

Received 1409 2019; Accepted 23032020

\begin{abstract}
Digitalization is becoming increasingly important in today's rural society as a vital driver in maintaining European rural areas competitive globally. Thereby, the research problem lays upon the potential of providing flexible support to overcome the digital divide in order to improve the business environment in rural areas. The paper aims to provide scientific review of two major research approaches: 1) digitalization impact on rural businesses development; 2) ICT role in life quality improvement and rural communities' development. The practical issue concerns the potential of providing flexible support to overcome the digital divide in order to improve the business environment and communities' infrastructure in rural areas. The research is performed through review of scientific articles from the last ten years, evaluating the trends of rural hubs development in Europe, including deeper understanding of digitalization, innovative development and communication financial support. The results section represents findings to determine innovative financial support models, considering European funds and regional financial initiatives potential, to strengthen digitalization in rural areas. Synergetic effect within all-European and local financial support and rural development strategies will boost hubs development, overcoming the digital divide in rural area. financing.

Keywords: digital divide, grant, hub, human development, investment, rural business and community, sources of

JEL Codes: G17, O13, O32, R00, R51.
\end{abstract}

\section{Introduction}

Despite rural regions make up roughly half of the EU territory with nearly one quarter of population living in these areas, most rural areas (81\%) recorded a GDP per inhabitant below the EU average (Collet, 2012; Pattinson and Dahlöf, 2019). The value added of agricultural industry in Europe has decreased from 1.563\% of GDP in 2013 to 1.44\% of GDP in 2018 (Agriculture..., 2018; Deshmane, 2016; A framework..., 2018; Valin et.al, 2014). Simultaneously, $88 \%$ of households in cities have access to internet, as opposed to $80 \%$ in rural areas. Only $40 \%$ of rural households have next generation access (fiber-based high-speed broadband) compared with $76 \%$ of total EU households (Augère-Granier, 2018; European Commission..., 2017). This means the restricted access to information and communications technology (urban-rural divide). Rural areas face a number of social and economic challenges for business and community, caused by digital urban-rural divide. On the one hand, reliable internet services are essential for improving the education and living conditions of rural people. In particular, among people aged 30 to 34, just over one quarter $(27.9 \%)$ of the EU population that was living in rural areas had a tertiary level of educational attainment in 2015; this share rose to one third (33.4\%) for people living in towns or suburbs, and peaked at almost half $(48.1 \%)$ among those living in cities (European Commission..., 2017). In some Eastern European countries, even if usually the level of education is quite high, there is still a problem of illiteracy that affects mainly rural areas.

Copyright (C) 2020. Published by Vytautas Magnus University. This is an open access article distributed under the terms of the Creative Commons Attribution Non-Commercial 4.0 (CC BY-NC 4.0) license, which permits unrestricted use, distribution, and reproduction in any medium provided the original author and source are credited. The material cannot be used for commercial purposes. 
The quality of education is often is lower in rural areas due to both qualifications of staff and level of education infrastructure, including access to information and communication technologies (ICT) equipment (Bertolini, Montanari and Peragine, 2008). In Lithuania, Portugal and Poland, only nearly half of the rural population made use of the internet on a daily basis in 2016, with this share falling to $42 \%$ in Greece, and close to one third of the rural population in Bulgaria and Romania (Eurostat..., 2017).

On the other hand, ICT plays an important role for rural business infrastructure development. Globally, about $20 \%$ of rural businesses generate at least $80 \%$ of their revenue by selling online (Infografic..., 2019). However, rural business representatives in Europe are not able to find candidates with the right kind of experience and education, with $39 \%$ and $35 \%$ of respondents respectively giving this answer. About $40 \%$ of rural business owners have troubles in accessing capital, mostly using their personal savings (71\%). At the same time, only $3 \%$ of European rural businesses use crowdfunding or online lender funding (Augère-Granier, 2018; Infografic..., 2019).

Thus, ICT widespread in rural areas is an essential factor both for rural society and business development. Rural digital hubs tend to develop skills and capacities of rural communities and businesses. Rural digital hubs offer a number of opportunities, including possibility to get fast, reliable internet access, physical workspaces and a range of business and community support services aimed to satisfy local needs. Because rural areas throughout Europe have been experimenting for over ten years with hubs and digital service centers to support the take up and application of digital technologies, the questions of their development and funding have received increased attention across several researches in recent years.

Several previous studies have found that the digital economy widespread provides assistance to overcome a wide range of economic and social challenges associated with rural areas (Philip and Williams, 2019). On the one hand, ICT plays a major role in bringing about business transformation in the rural areas (Deshmane, 2016). ICT diffusion is a significant driver for business expansion in rural areas, concerning impact on the productivity and business effectiveness (Aleke et al., 2011). In particular, digitalization provides opportunities for rural businesses development, including local income growth support (Whitacre et al., 2014) and new markets emergence (Huggins and Izushi, 2002). The access to finance remains a major challenge for innovative rural business in most countries, including digital hubs development in the rural areas (Onumah and Meijernik, 2017).

On the other hand, ICT is still dealing with both the problems of rural development and rural poverty (Bertolini, Montanari and Peragine, 2008). In order to get the full value from investments in broadband infrastructure, rural communities need to understand the usefulness of digital applications (Rural development..., 2019). Researches on digital technologies development in rural areas have so far focused on ICT role in life quality improvement and economic development in rural communities (Hosman and Fife, 2008; Kozma, 2005; Damsa et.al, 2010). Considering recent social and economic trends, inadequate broadband internet service is the reason of higher risk of poverty in European rural areas $(26 \%)$ than in cities (24\%) (Fernández-Olit et.al, 2018). Rural areas citizens often have more limited access to digital services (Augère-Granier, 2018). At the same time, despite the long tradition of intervention, rural poverty is still an important issue to face in the economic and social growth of developed countries. The digital engagement and behavior problem still remain under-researched for rural areas (Townsend et al., 2017).

Digitalization issues have been the topic of academic researches regarding the actual trends of rural development in recent years. The sustainable economy presents a necessity for the worldwide delivery of ICT in rural areas, enabled by investing (Statistical..., 2013; Jekabsone and Skribane, 2018). In accordance with EU2020 strategy, there is a need for innovative and ICT development in rural areas to achieve "sustainable rural intensification". Digital technologies and their implementation by EU farmers are considered as main drivers in maintaining European agriculture competitive globally (Agricultural..., 2019). The rural development funding strategies are represented both within national and European development policies (Rural development..., 2019). Digitalization in European rural areas are funded through funds. National and local governments 
have invested significant amount of public funding in supporting rural digital infrastructure upgrades. Considering recent global tendencies of social and economic development, it is important to pay attention to the innovative rural development financing models.

This article presents the systematic review of two major research approaches: 1) digitalization impact on rural businesses development; 2) ICT role in life quality improvement and rural communities' development (the scientific problem). The practical issue concerns the potential of providing flexible support to overcome the digital divide in order to improve the business environment and communities' infrastructure in rural areas. The hypothesis of the paper has both theoretical and applied background, concerning the impact of digitalization on European rural hubs development and the peculiarities of their financial support. This paper aims to provide scientific support on building and financing of digital skills and capacities of rural business and community within hubs. The object of the research is digitalization boost within rural hubs. The subject is ICT financing volumes and sources, contributing to the European rural area's development.

The research methodology is based on the achievements of European scientists and rural areas surveys. The research is performed through review of scientific articles from the last ten years, evaluating the trends of rural hubs development in Europe, including deeper understanding of digitalization, innovative development and communication financial support. Based on previous researches and considering the specifics of bridging the urban-rural digital divide in Europe, methods of evaluating the ICT effectiveness in rural areas and its funding peculiarities, the following aspects are taken into account:

1. The comprehensive literature surveying is performed on the selected topic of digital technologies in rural areas, concerning urban-rural divide, ICT development and financing. Web of Science Core Collection, Scopus and Google Scholar databases are reviewed for this purpose. This summarizes the reason why rural digital hubs are important, how they work, and what it takes to do that work in Europe.

2. The primary data of rural development and financial support reports are provided to confirm the trends of social and economic development in European rural areas. The analysis is based on the OECD (A framework..., 2018), the European Commission (European Commission, 2017), Eurostat (Eurostat..., 2017) and the World Bank data (Agriculture..., 2018). These databases are used to create figures on rural hubs development trends. The particular attention is paid to the rural hub's development in Europe, socio-economic assessment of their financial support.

3. A combination of quantitative and qualitative approaches is used to analyse the principles of rural hubs financial support. This provides robust evidence for rural areas with ICT transfer potential financing.

The current research consists of the following parts: primarily, a theoretical framework based on rural hubs definition and possibilities of their financing is provided; then, possibilities for rural hubs diversification in Europe are described; the options for financial support increase in European rural areas are examined.

The research practical implication is that results can be used within rural hubs development and financial support strategies to accept both business and community challenges in Europe.

\section{Main theoretical assumptions of the research 2.1. Rural hubs and their digital drivers}

To advance understanding of rural hubs and their digital drivers, the present study comprises a systematic literature review with specific focus on research related to ICT management in rural areas. To date, existing studies have been carried out on digital hubs general definition, considering them as a central point for rural development (Toivonen and Friederici, 2015). In particular, it may be defined as "a physical space, which can be fixed or mobile, focused on digital connectivity, digital skills and/or emergent technologies; the space will be available to either the public, businesses, or 
local authorities (or a combination) with the aim of enhancing the local digital environment" (CORA..., 2019).

The primary ideas of hub development are considered by Porter (2000) and outlined in the context of clustering and complementary businesses models. The cooperation within complementary businesses models (hub) is the cause of synergetic effect, which means the widespread of personal skills and knowledge within the business structures, either through the supply chain or by virtue of employees moving between businesses, spreads both codified and tacit knowledge (Cooke et. al., 2002; Caniels and Romijn, 2005). The Aspen Institute experts define rural hubs as key players, advancing an asset-based and wealth-building approach to rural community and business development (Rural hubs..., 2019).

Currently, digital technologies and innovations are transforming many sectors, including the spread of ICT in rural areas that creates additional opportunities to integrate rural business representatives in new digitally driven agrifood systems (Glaeser and Shapiro, 2003; USAID, 2018). However, there are different points of views on rural hubs functionality, considering them either business- or community-focused. On the one hand, the European Commission aims to support rural business and ventures, enhancing digital innovation hubs network (Technologies..., 2018). On the other hand, the meaning of "hubs", "networks", "incubators", "clusters", etc. is considered in the context of rural community development (European Commission..., 2017). The main debated question determines common features and diversity of above-mentioned organizational structures (CORA..., 2019).

Rural digital hubs offer both territory for offline activity and fast, reliable on-line access that provide a wide range of business and community support services in rural areas (Revitalising..., 2017). Digital hubs aim to provide growing connectivity in rural areas, engaging the local community and attracting businesses (Figure 1).

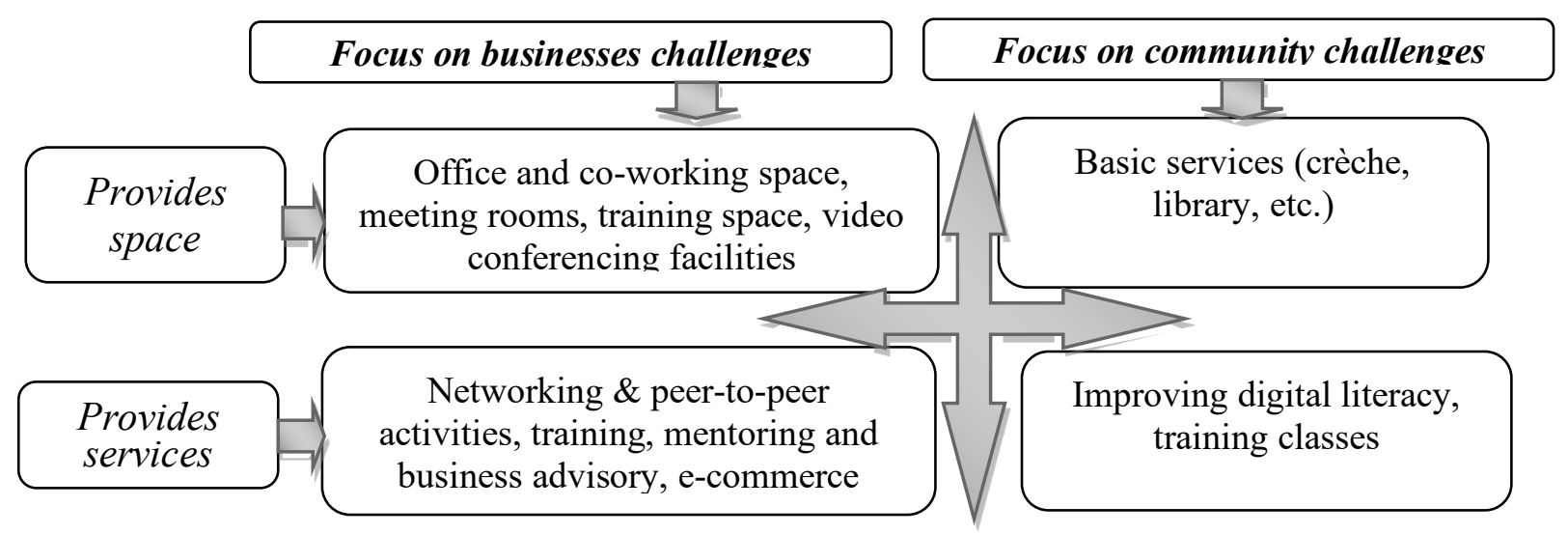

Figure 1. Matrix of digital rural hubs

Recent trends of social and economic development in rural areas have heightened the need for utilization, protection and enhancement of the natural, physical and human resources that provide the possibility to make long-term improvements in rural living conditions (Deshmane, 2016). At the same time, many "smart" farms are faster and more economical efficient, in case they are taking advantages of reliable internet access and online support services within digital hubs (Revitalising..., 2017).

\subsection{Innovative models of rural development financing}

Financial support plays an important role in building capabilities for the rural digital hubs. The high number of rural SMEs, around 11.3 million farmers and other agricultural companies, results in a lack of financial resources to invest successfully in digital solutions (Anda, Lora, Molina, 2019). Despite recent successful trends of digital hubs development there is still a low progress in the 
rise of alternative finance. Thereby, rural areas should consider the possibilities to improve innovative models of rural development financing (Table 1) (Onumah and Meijernik, 2017).

Table 1. Innovative models of rural development financing

\begin{tabular}{|l|l|l|}
\hline \multicolumn{1}{|c|}{ Innovative model } & Main sources of financing & \multicolumn{1}{|c|}{ Main focus within digital hub } \\
\hline $\begin{array}{l}\text { Expanding access to rural finance: by linking } \\
\text { community-based financial organizations to larger } \\
\text { formal financial intermediaries }\end{array}$ & $\begin{array}{l}\text { EU funds, national, regional, } \\
\text { local government }\end{array}$ & Community \\
\hline $\begin{array}{l}\text { Expanding access to rural finance: promoting } \\
\text { rural/community banking }\end{array}$ & Citizen groups & Community \\
\hline $\begin{array}{l}\text { Innovative group-based, mutual credit guarantee } \\
\text { schemes }\end{array}$ & Commercial providers & Business \\
\hline Easing access to collateral in farm households & Citizen groups & Community \\
\hline Delivering financial services via mobile technology & Other & Business / Community \\
\hline Value chain financing & Other & Business \\
\hline Local Purchase Order and receivables financing & Other & Business \\
\hline Lead firm financing & Business & Business \\
\hline $\begin{array}{l}\text { Improving acess to finance through third-party } \\
\text { mitigation of risk }\end{array}$ & Business & Business \\
\hline
\end{tabular}

Thus, innovative models of rural development financing are emerging to enhance financial support in rural value chains.

\section{Results of the research and discussion}

\subsection{Rural digital hubs in Europe}

In accordance with the strategy on Connectivity for a European Gigabit Society, adopted in 2016, the European digital single market development will bring many economic and social benefits, overcoming both business and community challenges (Figure 2) (Eurostat..., 2017).

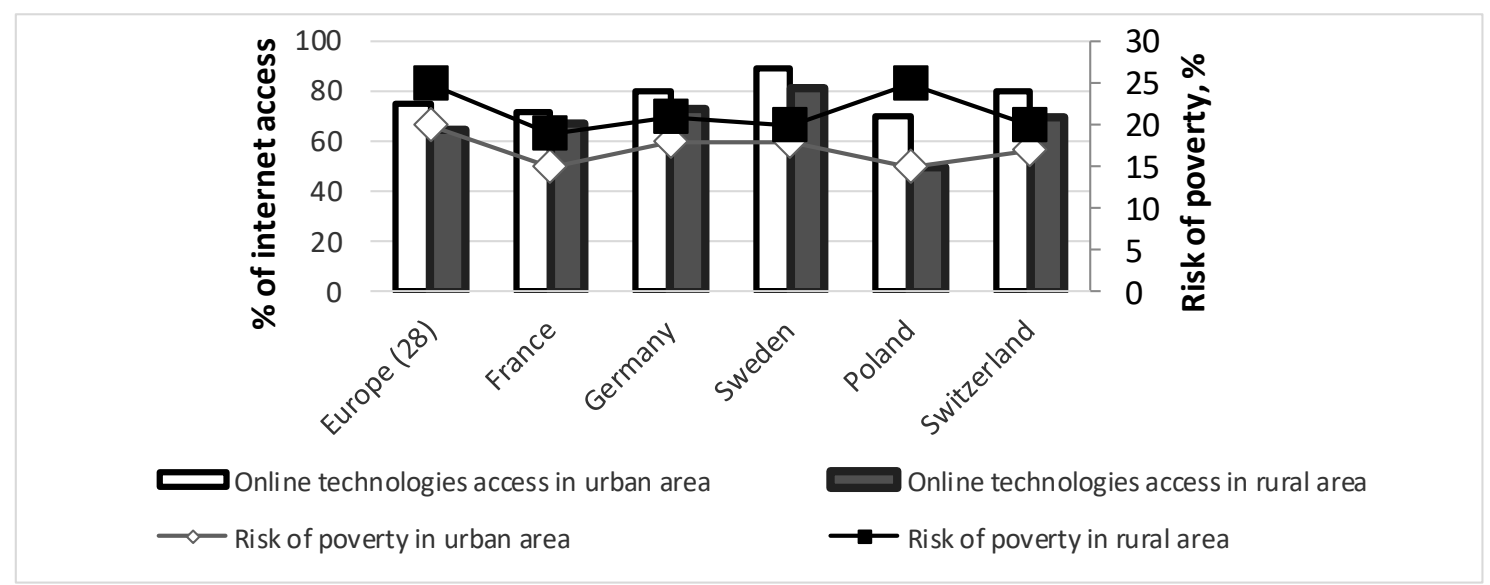

Figure 2. The risk of poverty and online technology access in European countries: rural and urban areas compartment (Eurostat..., 2017) 
The Eurostat researches show the tendencies of poverty risk and internet accessing in European countries. Namely, the rural areas have higher poverty risk and less internet access than the urban ones. Despite the fact that all European citizens should have access to internet speeds higher than $100 \mathrm{Mbps}$ by 2025, there is a number of structural disadvantages in rural areas, including lack of business vision for enterprises, geographical barriers in terms of access to public services, limited digital skills and competences (Philipa et. al., 2017; CORA..., 2019). This provides barriers for European digital market development. Digital hubs development is the functional decision to

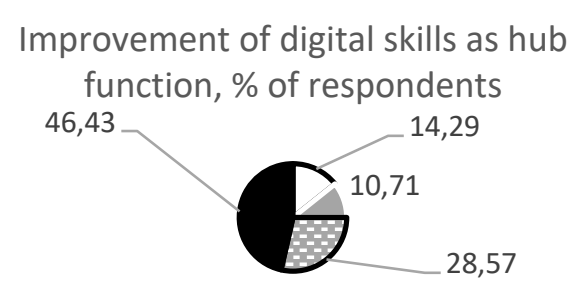

口Disagree $=$ Rather agree $\mathbf{\square}$ Agree avoid such barriers (Figure 3).

\section{Delivery internet access as hub function,} $\%$ of respondents

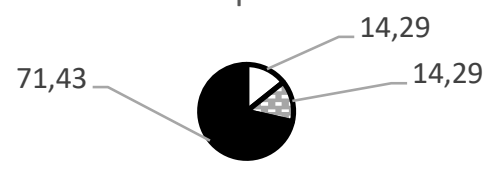

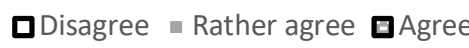

Totally agree
Meeting and networking space as hub function, \% of respondents

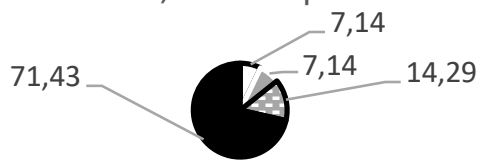

口Disagree $\boldsymbol{n}$ Rather agree $\boldsymbol{\square}$ Agree $\boldsymbol{\square}$ Totally agree

Contact to other initiatives related to

digital innovation and stackholders as

hub function, \% of respondents

50,00

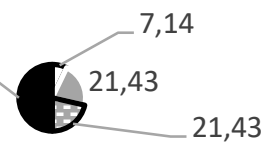

口Disagree $\approx$ Rather agree $\boldsymbol{\square}$ Agree

Totally agree Agree

\section{Figure 3. Common Hub Functions (CORA..., 2019)}

The CORA Digital Hub Guide provides an overview of Digital Hubs and their potential place in enhancing the rural digital landscape. This survey was targeted for the set sample of CORA project partners (14) that were contributing to a 'baseline' for the project. The question was on hub functionality. The scale of answers is from 0 to 5, where 0 is Totally Disagree and 5 is Totally

The most common feature that hub respondents "totally agreed" with was delivering internet access. This seems to be an integral feature of all rural digital hubs (CORA..., 2019). Thereby, hubs creation stimulates digital innovation in rural areas, enabling local authorities to fill in different digital gaps (Table 2).

Table 2. Matrix of rural digital hubs in Europe (CORA..., 2019)

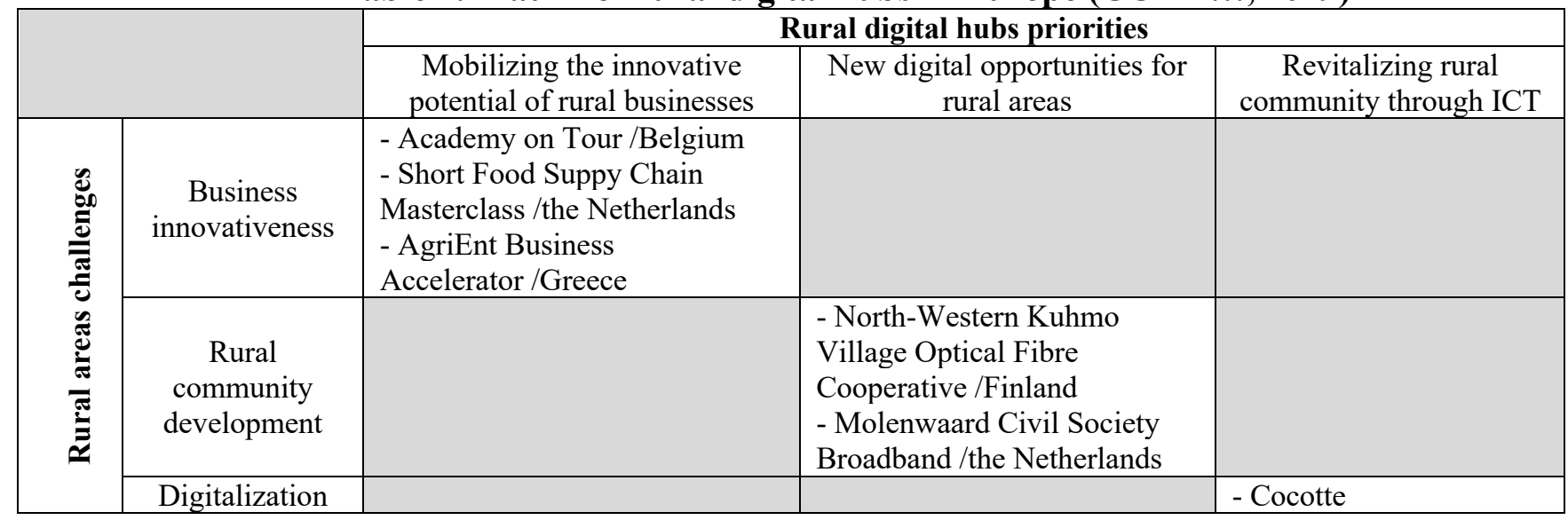




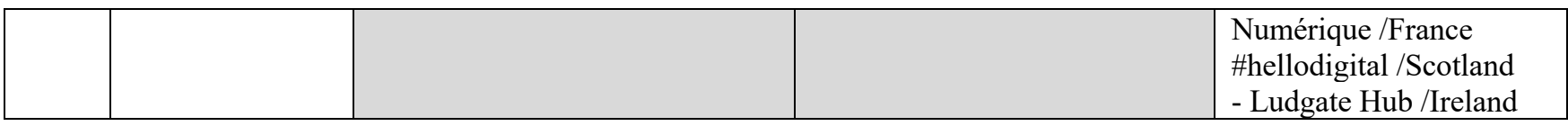

Thus, there is high diversity among digital hubs functions in Europe that determines the need to diversify their financial support sources.

\subsection{Financial support of rural digital capacity in Europe}

Digital capacity in European rural areas gets support from both specialized all-European funds and local initiatives (CORA..., 2019) (Figure 4).

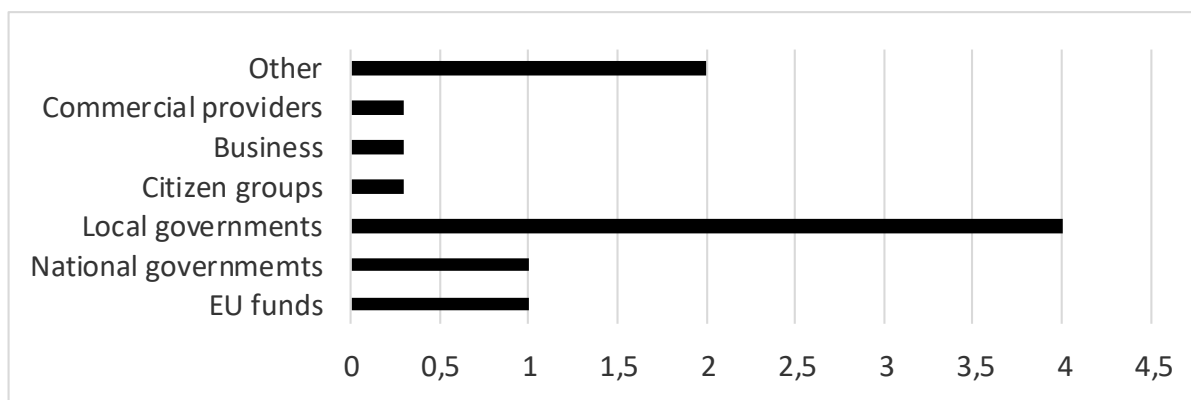

Figure 4. Estimation of stakeholders, supporting digital hubs in Europe (in accordance with CORA Digital hub survey) (CORA..., 2019)

The CORA Digital Hub Guide provides an overview of Digital Hubs and their potential place in enhancing the rural digital landscape. This survey was targeted for the set sample of CORA project partners (14) that were contributing to a 'baseline' for the project. The question was on financial mechanisms, which are mainly used to develop rural hubs in the age of digitalization. The scale of answers is from 0 to 5 , where 0 is "the financial mechanism is hardly used" and 5 is "the financial mechanism is totally used".

Hubs identified that local governments are more active, supporting digital hubs, than national governments or business (CORA..., 2019). The European rural policy provides financing through the European Agricultural Fund for Rural Development (EAFRD). In particular, EAFRD provides financial support for Molenwaard Civil Society Broadband (The Netherlands) and North-Western Kuhmo Village Optical Fibre Cooperative (Finland). The European Innovation Partnership for Agricultural productivity and Sustainability (EIP-AGRI) supports rural innovation in Europe by combining the efforts of public and private entities, concerning agrarian production demand and supply. The digital potential of rural areas is developed within the Rural Renaissance call of the Horizon 2020 work program. Innovation and digital technology in rural areas are among the European priorities of the Smart Specialization Platform for Agri-Food (European agricultural..., 2019; EIP-AGRI, 2019). In accordance with European network for rural development (ENRD) forecast (Figure 5), EURO 24 bn from European funds will be spent on different priorities of rural hub development that makes nearly 16\% of RD expenditures in 2020 (Rural development..., 2019).

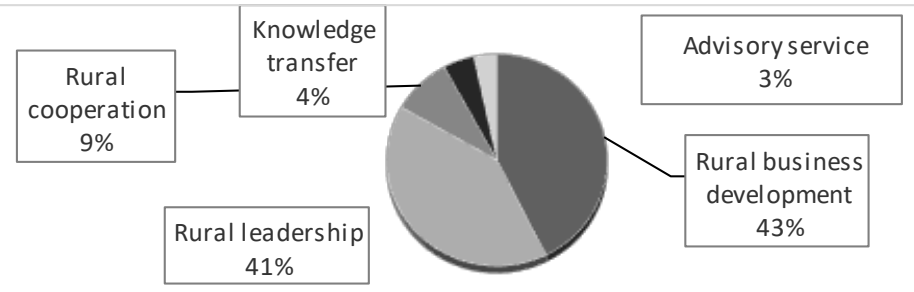

Figure 5. Structure of rural hub development financial support from European funds in 2020 (in accordance with ENRD forecast)

In addition to all-European rural development financial support programs, there are many 
regional initiatives. Academy on Tour project (Belgium), which provides assistance for Flemish farmers, searching for inspiration and professional assistance within the process of highly innovative business idea development and realization, is financed under the Flemish RDP (65\%) and from national sources (35\%). The main sources for Short Food Supply Chain Masterclass (the Netherlands) are the provincial government of South Holland (contributes around 65\% under its provincial Green program) and the municipality of Rotterdam through its already established Food Cluster (25\%). AgriEnt Business Accelerator (Greece) is non-profit partnership that has organized the first agricultural business accelerator process in Greece. The partly support is provided by the Greek Volunteer Centre Managers Association Greece (KEMEL) and the Greek Agronomy Association (professional network). Thus, digital hubs have the potential to drive rapid progress in European rural areas as the result of synergetic effect from its diversified financial support.

\section{Conclusions}

1. The primary set of analyses provides the evidence on significant benefits for rural area, caused by digitalization. The digital divide affects people living in poverty in rural areas by limiting the access to achieve enhancement of social capital. Thus, hubs are modern organizational forms to develop both rural business and community that creates a prospect for further researches in such direction.

2. The current research provides insights into the innovative models of rural development financing. This provides the potential to accept a major challenge for digital hubs financing and development.

3. European experiences show the highly diversified rural hubs functionality, including digital, innovative and community development hubs. Thus, this shows the requirement to finance different types of ICT implementation in rural area.

4. All-European and local rural investments are considered as an important feature of rural development. Thus, the European rural community faces the urgency for constantly financial support of rural digital capacity.

5. The increase of ICT access in rural areas reduce the gap between social and economic development in rural and urban areas, overcoming the digital divide in rural area.

\section{References}

A framework for rural development. Rural 3.0. (2018). - Paris: OECD. 27 p.

Agricultural technological innovation. (2019). EU Science hub. - https://ec.europa.eu/jrc/en/researchtopic/agricultural-technological-innovation [14 06 2019]

Agriculture, forestry, and fishing, value added. (2018). The World Bank. https://data.worldbank.org/indicator/NV.AGR.TOTL.ZS?locations=EU [2019 09 15]

Aleke, B., Ojiako, U. Wainwright, D. (2011). Social networks among small agribusinesses in Nigeria. // Society and Business Review. Vol. 6. No 3: 214-228.

Anda, J., Lora, A., Molina, N. and other. (2019). SmartAgriHub. Needs assessment report. WP 4. - Brussel: EU. $204 \mathrm{p}$.

Augère-Granier, M. Urban-rural divide: Blame it all on my roots. European Parliament. http://www.europarl.europa.eu/RegData/etudes/ATAG/2018/614753/EPRS_ATA(2018)614753_EN.pdf [14 06 2019]

Bertolini, P, Montanari, M., Peragine, V. (2008). Poverty and social exclusion in rural areas executive summary. - Brussel: European Commission. 29 p.

Caniëls, M., Romijn, H. (2005). Agglomeration advantages and capability building in industrial clusters: the missing link. // Journal of Development Studies. No. 3: 187-210.

Collet, I. (2012). The economy of EU rural regions. General and regional statistics. -Luxemburg: Eurostat. 12 p.

Cooke, P., Braczyk, H., Heidenreich, R. (2002). Regional innovation system: an evolutionary approach. Regional Innovation Systems. - London: UCL Press. 196 p.

CORA Digital Hub Guide. (2019). An operational guide to setting up and running a Digital Hub. - United Kingdom: Lincolnshire. 43p.

Damsa, C. I., Kirschner, P. A., Andriessen, J. E. B., Gijsbert, E. (2010). Shared Epistemic Agency: An empirical study of emergent construct. // The Journal of the Learning Sciences. Vol. 19. No. 1: 143-186. 
Deshmane, S. (2016). Impact of Science and Technology on Indian Rural Society: A Sociological Study // Imperial Journal of Interdisciplinary Research. Vol. 2. No. 13: 39-42.

EIP-AGRI. (2019). European Innovation Partnership. Agricultural Productivity and Sustainability. https://ec.europa.eu/eip/agriculture/en/european-innovation-partnership-agricultural [14 06 2019]

European Agricultural Fund for Rural Development. (2019). European Structural and Investment Funds (ESIF). - https://www.europe-en-france.gouv.fr/en/european-funds/european-agricultural-fund-rural-development-EAFRD [14 06 2019]

European Commission joins forces to help bringing more broadband in rural areas (2017). https://ec.europa.eu/digital-single-market/en/news/european-commission-joins-forces-help-bringing-more-broadbandrural-areas [14 12 2019]

Eurostat. (2017). Statistics on rural areas in the EU. - https://ec.europa.eu/eurostat/statisticsexplained/index.php/Statistics_on_rural_areas_in_the_EU [16 09 2019]

Fernández-Olit, B., Paredes-Gázquez, J. D., Cuesta-González, M. (2018). Are social and financial exclusion two sides of the same coin? An analysis of the financial integration of vulnerable people. // Social Indicators Research. Vol. 135. No. 1: $245-268$.

Glaeser, E. L., Shapiro, J. M.. (2003). Urban Growth in the 1990s: Is City Living Back? // Journal of Regional Science. Vol. 43. No. 1: 139-165.

Hosman, L., Fife, E. (2008). Improving the prospects for sustainable ICT projects in the developing world. // International Journal of Media and Cultural Politics. Vol. 4. No 1: 51-69.

Huggins, R., Izushi, H. (2002). The digital divide and ICT learning in rural communities: examples of good practice service delivery. // Local Economy: the Journal of the Local Economy Policy Unit. Vol. 17. No 2: 111-122.

Infographic: Rural Entrepreneurship. SCORE 2019. - https://www.score.org/resource/infographic-ruralentrepreneurship [2019 09 15]

Jekabsone, S., Skribane, I. (2018). Investments in Latvia // Regional Formation and Development Studies. No. 1(24): $35-43$.

Kozma, R. (2005). National Policies That Connect ICT-based Education Reform to Economic and Social Development // Interdisciplinary Journal of Humans in ICT Environment. Vol. 1. No 2: 117-156.

Onumah, G, Meijernik, G. (2017). Innovative Agricultural financing models. // Policy brief. No. 6: 2-6.

Pattinson, M., Dahlöf, C. (2019). The challenges and necessity of rural innovation. European regional development fund. - Brussels: EU. 13 p.

Philip, L., Williams, F. (2019). Remote rural home based businesses and digital inequalities: Understanding needs and expectations in a digitally underserved community. // Journal of Rural Studies. Vol. 68: 306-318

Philipa, L., Cottrilla, C., Farringtona, J., Williamsb, F., Ashmore, F. (2017). The digital divide: Patterns, policy and scenarios for connecting the 'final few' in rural communities across // Great Britain Journal of Rural Studies. Vol. 54: 386-398. 1: 78-93.

Porter, M. E. (2008). The five competitive forces that shape strategy. // Harvard Business Review. Vol. 86. No.

Revitalising rural areas through digitization. The experience of three rural digital hubs. (2017). European network for rural development. - https://enrd.ec.europa.eu/publications/rural-businesses-rural-digital-hubs_en
Rural
development
2014-2020.
(2019).
Agriculture
and
rural
development.

https://ec.europa.eu/agriculture/rural-development-2014-2020_en [14 06 2019]

Rural hubs. Strengthening Rural Innovation Infrastructure. (2019). Community Strategy Group. - Washington: The Aspen Institute. 64 p.

Statistical Digest of Rural England. (2013). Report. - London: Defra. 118 p.

Technologies and systems for digitizing industry (Unit A.2). (2018). Pan-European network of DIHs. https://ec.europa.eu/digital-single-market/en/digital-innovation-hubs [14 08 2019]

Toivonen, T., Friederici, N. (2015). Time to define what a "hub" really is. // Stanford Social Innovation Review. - https://ssir.org/articles/entry/time_to_define_what_a_hub_really_is [16 09 2019]

Townsend, L., Wallace, C., Fairhurst, G., Anderson A. (2017). Broadband and the creative industries in rural Scotland // Journal of Rural Studies. Vol. 54: 451-458.

USAID. (2018). Digital farmer profile: Reimagining Smallholder Agriculture. - Washington D.C.: USAID. 91 p.

Valin, H., Sands, R., Nelson, G. (2014). The future of food demand: understanding differences in global economic models // Agricultural economics. Vol.45. No. 1: 51-67.

Whitacre, B., Gallardo, R., Strover, S. (2014). Broadband's contribution to economic growth in rural areas: moving towards a causal relationship. // Telecommunications policy: the international journal of ICT economy, governance and society. Vol. 38. No 11: 1011-1023. 